Acta vet. scand. 1987, 28, 393-402.

From the Department of Veterinary Microbiology, Section of Parasitology, University of Agricultural Sciences and the National Veterinary Institute, Uppsala, Sweden.

\title{
Seroresponse (IgG) after Vaccination and Natural Infection of Cattle with Babesia Divergens
}

\author{
By D. A. Christensson \& T. Morén.
}

\begin{abstract}
Christensson, D. A. and T. Morén: Seroresponse (IgG) after vaccination and natural infection of cattle with Babesia divergens. Acta vet.sand. 1987, 28, 393-402. - The antibody response against Babesia divergens in vaccinated calves and in unvaccinated sentinels on farms where vaccination had been practiced routinely, was investigated using a live vaccine.

Sera were obtained before and 3 weeks after vaccination in March and April, approximately 1 month before the animals were put out on pasture.

Additional blood samples were collected at the end of the grazing season and again the next spring. At that time previously unvaccinated sentinel calves were vaccinated and their antibody response was tested 3 weeks later. All sera were analysed by an IF-technique. All of the vaccinated calves $(100 \%)$ were seropositive 3 weeks after vaccination. The seroresponse did not differ signifacantly between animals vaccinated before their first or second grazing season although the age difference was about 12 months. No clinical symptoms of babesiosis were seen in vaccinated animals. The titres were, however, significantly higher 3 weeks after vaccination than 6 months later.

After the grazing season about $42 \%$ of the unvaccinated sentinel calves were seropositve. Two of these calves had clinical babesiosis on pasture in July and September respectively.

The number of sentinel calves which became infected on pasture showed a large farm-to-farm variation although all cattle on the farms once had been infected/vaccinated with B. divergens. Probably the different number of calves infected was a reflection of a variation in tick density on the different pastures.

All calves, which were seropositive after the grazing season, were also seropositive after 6 months indoors. The titres declined during the winter period, but they were still within the range of 2 doubling dilution steps.
\end{abstract}

\section{Introduction}

Humoral antibodies after vaccination of cattle in the field with living organisms of Babesia bovis and B. bigemina has been reported by Ross \& Löhr (1968), Goldman \& Pipano (1974), Todorovic et al. (1975), and Callow (1977) among others and antibody response after vaccination with $B$. divergens has been reported by Taylor et al. (1980) and Purnell et al. (1981).
In cattle vaccinated or naturally infected with living Babesia organisms a subclinical infection, a babesiosis, may develop. This state of dynamic equilibrium between the Babesia and the host may persist for at least 3-7 years as shown for B.divergens by Joyner \& Davies (1967) and for B.bovis by $M a-$ honey (1969).

Vaccine aginst Babesia in Sweden has been produced annually since 1928 (Heijbel 1928, 
Bodin \& Hlidar 1963). However, this is the first account on the serological response of calves to this vaccine in comparison with the antibody response of naturally infected calves.

The aim of the present investigation was to define the seroresponse in calves: after vaccination, after a subsequent natural exposure to B.divergens and after a subsequent period of about 6 months, when the animals were reared indoors. Furthermore, the seroresponse after vaccination of both the naturally infected and the uninfected sentinel calves was elucidated.

\section{Materials and methods}

\section{Animal and experimental design}

Clinical babesiosis has been reported as occurring most commonly in the south-eastern counties of Sweden (Olson 1961, Wahlgren et al. 1984). Ten 30-40-cow dairy herds in this area were selected for this study. All herds had been routinely vaccinated against babesiosis annually for the last 5 years at least. The calves, all but 1 being heifers, were born on their respective farms as were the dams. The dams had been vaccinated against babesiosis as calves and they had been on grass every summer. During the preceding 2 years outbreaks of clinical babesiosis had occurred among adult cows in 3 of the herds (herds no. 4,5 and 7).

Ten calves in each herd were made available for this investigation. Five of these calves were vaccinated according to the farmers practice and 5 were left unvaccinated as sentinel calves. These groups of primarily unvaccinated calves were vaccinated at first 12 months later. The average age at the day of vaccination was 9 months (range 4-18 months) of the vaccinated calves respectively 8 months (range 3-17 months) of the sentinel calves.
The calves were on grass from the end of May until October. All of the calves in the herd grazed together during the entire grazing season. The pastures were old permanent grassland, which had been grazed by the same category of animals for many years.

Therefore it is postulated that any existing tick population would be infected with B.divergens derived from vaccinated cattle.

\section{Vaccine}

The B.divergens vaccine was produced by the National Veterinary Institute. The production technique was basically the same as that described by Callow (1977) for B.bovis vaccine in Australia. Blood was drawn from an infected splenectomized calf at a parasitaemia at about $10 \%$ infected red blood corpuscles (rbc). To prepare vaccine, this blood was diluted in Hanks solution to which Nacitrate $0.3 \mathrm{~mol} / 1,0.5 \%$ laceral albumin, 500 IE penicillin/mg and $100 \mathrm{ug}$ streptomy$\mathrm{cin} / \mathrm{ml}$ were added. The blood was diluted to contain $3 \cdot 10^{7}$ infected rbc per ml. Daily losses of infective Babesia organisms in stored blood was compensated as described by $\mathrm{Cal}$ low (1977). Both a freshly prepared and a stored vaccine were used. The freshly prepared product was inoculated within 4 days after the blood had been collected from the donor calf. The stored vaccine was manufactured from blood that had been kept for 7 days in a refrigerator at $+4-+8^{\circ} \mathrm{C}$. This stored vaccine was used in herds no. 2,3 , and 4. The vaccine used in this experiment consisted of 4 batches prepared at different times, originating from the same isolate of B.divergens (A 79-1). Each dose of vaccine contained $3 \times 10^{7}$ erythrocytes infected with infective B.divergens organisms. Three $\mathrm{ml}$ of the vaccine were inoculated subcutaneously (s.c.). 


\section{Vaccination routines}

The freshly manufactured vaccine reached the local veterinary practitioners by mail within 24 hs. The calves were inoculated the following day at the latest.

Vaccination took place in March or April in 1980 , and was completed at latest 4 weeks before the cattle were let out on pasture. After vaccination the animals were clinically observed daily by the farmers for 3 weeks. The sentinel calves were vaccinated a year later following the same routines.

\section{Serum samples}

Blood samples were collected from all of the calves in both the vaccinated and the unvaccinated groups at the following times:

A. Day of vaccination 1980 .

B. Three weeks after vaccination.

C. Six to seven months after vaccination, i.e. after the end of the grazing season.

D. In March or April 1981, i.e. 12 months after the first vaccination when also the previously unvaccinated sentinel calves were vaccinated. At this point the calves had been indoors since the end of the grazing season about 6 months earlier.

Moreover, samples were collected from the sentinel calves 3 weeks after the vaccination in 1981 . However, herd no. 8 was then excluded from this investigation due to a changed practice of the farmer.

The calves with clinical babesiosis were sampled at the very first appearance of symptoms.

Serum was separated by centrifugation and stored at $-20^{\circ} \mathrm{C}$ until used.

\section{IF-test}

The IF-test previously described by Goldman (1968) was modified using fluorescein conjugated protein A (Christensson 1987). All samples were titrated in doubling dilutions to their endpoints, starting at a dilution of $1 / 40$, which was regarded as the minimum positive reaction. The anti-immunoglobulin used was a rabbit monospecific antibovine IgG (Miles Ltd.).

\section{Statistical analysis}

For statistical analysis the mean titre value of seropositive $(\geq 1 / 40)$ animals in each group was calculated as the sum of ${ }^{10} \log$ of the reciprocal titre values divided by the number of seropositive animals.

The difference in herd mean titre values between herds and between different sampling occasions within herds were analysed using the $t$-test. Heterogeneity between frequencies were analysed using the $\mathrm{X}^{2}$-method with Yates correction factor. The group mean titre values of seropositive animals were also analysed when herds were grouped with regard to the number of seropositive sentinel calves after grazing (Tables 2-4).

\section{Clinical babesiosis}

Animals which had clinical babesiosis were treated with chinuridmethylsulphate, 1 $\mathrm{mg} / \mathrm{kg}$ b.w. (Acaprin ${ }^{\mathrm{R}}$ ). The diagnosis was confirmed by reading thin blood films stained with acridin-orange according to Trees (1974).

\section{Results}

I. Animals vaccinated before their first grazing season

All animals were seronegative for Babesia divergens at the day of vaccination (A). They were seropositive 3 weeks after vaccination (B), at the end of the grazing season (C), and after additional 6 months indoors (D) (Table 1).

The herd mean antibody titres and the total individual mean titres are presented in Table 2 . At 3 weeks after vaccination the mean individual titre value was $1 / 680$, (range $1 / 160$ 1/2560). The corresponding figures after 6 
Table 1. Babesia divergens IgG-positive calves, vaccinated and unvaccinated, on the same pastures. The same individuals, five in each group in each herd (no. $8=4$ unvaccinated), were examined at each occasion. At day of vaccination all calves were seronegative.

\begin{tabular}{lccccccc}
\hline & \multicolumn{6}{c}{ No. of B.divergens IgG-positive calves } \\
\cline { 2 - 7 } Herd & \multicolumn{2}{c}{ Before grazing } & \multicolumn{2}{c}{ After grazing } & \multicolumn{2}{c}{ After housing } \\
\cline { 2 - 7 } no. & $\begin{array}{l}3 \text { weeks after } \\
\text { vaccination }\end{array}$ & $\begin{array}{c}\text { unvac- } \\
\text { cinated }\end{array}$ & $\begin{array}{c}6 \text { months after } \\
\text { vaccination }\end{array}$ & $\begin{array}{c}\text { unvac- } \\
\text { cinated }\end{array}$ & $\begin{array}{c}12 \text { months after } \\
\text { vaccination }\end{array}$ & $\begin{array}{c}\text { unvac- } \\
\text { cinated }\end{array}$ \\
\hline 1 & 5 & 0 & 5 & $5^{\mathrm{b}}$ & 5 & 5 \\
2 & 5 & 0 & 5 & 4 & 5 & $3^{\mathrm{a}}$ \\
3 & 5 & 0 & 5 & 3 & 5 & 3 \\
4 & 5 & 0 & 5 & 3 & 5 & 3 \\
5 & 5 & 0 & 5 & $2^{\mathrm{b}}$ & 5 & 2 \\
6 & 5 & 0 & 5 & $2^{\mathrm{a}}$ & 5 & 2 \\
7 & 5 & 0 & 5 & 1 & 5 & 1 \\
8 & 5 & 0 & 5 & 0 & 4 & 0 \\
9 & 5 & 0 & 5 & 0 & 5 & $4^{\mathrm{a}}$ \\
10 & 5 & 0 & 5 & 0 & 5 & 0 \\
\hline No. animals & & & & & & 46 \\
Examined & 50 & 49 & 50 & 48 & 49 & 19 \\
Seropositive & 50 & 0 & 50 & 20 & 49 & 41.3 \\
Inf.- \% & 100.0 & 0.0 & 100 & 41.7 & 100 & \\
\hline
\end{tabular}

a1 animal was sold

b1 animal had clinical babesiosis

months were $1 / 358$ (range $1 / 80-1 / 1280$ ) and after 1 year $1 / 177$ (range $1 / 40-1 / 2560$ ). Animals with initially high titres dropped the most dilution steps, but some individuals actually gained 2-3 dilution steps during the winter period indoors. There was a significant difference in the total individual mean titre values considering "ALL « animals between 3 weeks p.i. and after grazing (Table 2) $(p<0.005)$, but there were no other consistent differences in mean titre values between herds, groups of herds or within the same herd at different sampling occasions. There was no evidence of clinical babesiosis closely to vaccination or later. There was no difference in the average herd antibody values between herds receiving different batches of te vaccine.
II. Animals unvaccinated before their first grazing season

Animals of this group were sentinel calves during the first grazing season. Before the next grazing season they were vaccinated; both animals which had not shown any seroconversion after grazing and those animals which had become seropositive.

\section{A. Sentinel calves before vaccination}

All sentinel calves were seronegative at time when the main herds were vaccinated (A) and 3 weeks later (B). At the end of the grazing season (C) in 1980, 20 out of 48 animals $(41.7 \%)$ still included in the group were seropositive (Table 1). Two calves had clinical babesiosis, one in July and the other in September. They had haematuria; increased bo- 
Table 2. Babesia divergens IgG antibody titres of vaccinated animals.

\begin{tabular}{|c|c|c|c|c|c|c|}
\hline \multirow[t]{3}{*}{ Herd no. } & \multicolumn{6}{|c|}{${ }^{10}$ Log. reciprocal B.divergens antibody titres. $\bar{x} \pm$ S.D. } \\
\hline & & Before grazing & & After grazing & & After housing \\
\hline & $\mathrm{n}$ & $\begin{array}{l}3 \text { weeks after } \\
\text { vaccination }\end{array}$ & $\mathbf{n}$ & $\begin{array}{l}6 \text { months after } \\
\text { vaccination }\end{array}$ & $\mathrm{n}$ & $\begin{array}{l}12 \text { months after } \\
\text { vaccination }\end{array}$ \\
\hline 1 & 5 & $2.8664 \pm 0.3840$ & 5 & $2.6857 \pm 0.4039$ & 5 & $2.5051 \pm 0.2129$ \\
\hline 2 & 5 & $3.0062 \pm 0.3657$ & 5 & $2.6255 \pm 0.4565$ & 5 & $2.5653 \pm 0.6864$ \\
\hline 3 & 5 & $3.0172 \pm 0.3596$ & 5 & $2.5051 \pm 0.3010$ & 5 & $2.1439 \pm 0.3924$ \\
\hline 4 & 5 & $2.8664 \pm 0.1104$ & 5 & $2.5653 \pm 0.2519$ & 5 & $2.1439 \pm 0.3924$ \\
\hline 5 & 5 & $2.9868 \pm 0.1459$ & 5 & $2.3245 \pm 0.3432$ & 5 & $2.3245 \pm 0.4039$ \\
\hline 6 & 5 & $2.9266 \pm 0.4966$ & 5 & $2.6858 \pm 0.2693$ & 5 & $2.2643 \pm 0.3297$ \\
\hline 7 & 5 & $0.7460 \pm 0.2390$ & 5 & $2.5654 \pm 0.3298$ & 5 & $1.7827 \pm 0.2692$ \\
\hline 8 & 5 & $2.5653 \pm 0.3185$ & 5 & $2.6858 \pm 0.3432$ & 5 & $2.1439 \pm 0.3297$ \\
\hline 9 & 5 & $2.4449 \pm 0.2355$ & 5 & $2.3245 \pm 0.1648$ & 5 & $2.0325 \pm 0.1648$ \\
\hline 10 & 5 & $2.8062 \pm 0.2904$ & 5 & $2.5653 \pm 0.1346$ & 4 & $2.6557 \pm 0.7166$ \\
\hline ALL & 50 & $2.8233 \pm 0.3443$ & 50 & $2.5533 \pm 0.3123$ & 49 & $2.4271 \pm 0.4515$ \\
\hline $\mathrm{HIGH}$ & 10 & $2.9363 \pm 0.3611$ & 10 & $2.6556 \pm 0.4076$ & 10 & $2.5352 \pm 0.4802$ \\
\hline LOW & 15 & $2.8864 \pm 0.3266$ & 15 & $2.5252 \pm 0.3311$ & 15 & $2.1238 \pm 0.4017$ \\
\hline NO & 15 & $2.6055 \pm 0.3051$ & 15 & $2.5252 \pm 0.2660$ & 14 & $2.2471 \pm 0.4848$ \\
\hline
\end{tabular}

ALL = all animals considered together

HIGH = herds where almost all sentinel animals became infected (nos. 1 and 2)

LOW = herds where few sentinel animals became infected (nos. 5, 6 and 7)

NO = herds where no sentinel animals became infected (nos. 8, 9 and 10)

dy temperatures of more than $40.5^{\circ} \mathrm{C}$ and parasitaemia. Although about $15 \%$ of their erythrocytes were infected the animals were seronegative at the time when treated. They were both seropositive when tested after the grazing season.

After 6 months indoors (D) 19 out of 46 animals (41.3\%) still included in the group were seropositive (Table 1). These seropositive animals were the same individuals as were previously seropositive. Twenty-three calves which were seronegative at housing remained so until they were vaccinated the following spring.

The herd mean antibody titres of the seropositive animals and the total individual mean titres of the seropositive sentinel calves are shown in Table 3. The mean individual titre value was $1 / 408$ (range $1 / 80-1 / 1280$ ) after the first grazing season in October. The corresponding figure after 6 months indoors was $1 / 357$ (range 1/80-1/1280). There was no significant difference in mean titre values between herds, groups of herds and witin the same herd at difference in mean titre values between herds, groups of herds and within the same herd at different sampling occasions when considering herds with seropositive animals.

\section{B. Sentinel animals after vaccination}

At the days of vaccination in March and April in 1981, 42 sentinel animals were still included in the study. They were now 15-29 months old, the average age being 20.3 months. 
Ta ble 3. Babesia divergens IgG antibody titres of unvaccinated sentinel calves which had been on grass for one season.

\begin{tabular}{lrccc}
\hline Herd no. & & \multicolumn{2}{c}{${ }^{10}$ Log. reciprocal B.divergens antibody titres $\overline{\mathrm{x}} \pm$ S.D. } \\
\cline { 2 - 5 } Herd no. & $\mathrm{n}$ & $\begin{array}{c}\text { After 6 months } \\
\text { on grass }\end{array}$ & $\mathrm{n}$ & $\begin{array}{c}\text { After subsequent } \\
6 \text { months indoors }\end{array}$ \\
\hline 1 & 5 & $2.7460 \pm 0.4946$ & 5 & $2.5653 \pm 0.3925$ \\
2 & 4 & $2.9567 \pm 0.1738$ & 3 & $2.6055 \pm 0.4598$ \\
3 & 3 & $2.5051 \pm 0.3010$ & 3 & $2.8062 \pm 0.3010$ \\
4 & 3 & $2.4048 \pm 0.1738$ & 3 & $2.5051 \pm 0.0032$ \\
5 & 2 & $2.3547 \pm 0.2129$ & 2 & $2.2041 \pm 0.4257$ \\
6 & 2 & $2.3546 \pm 0.2128$ & 2 & $2.2041 \pm 0.4257$ \\
7 & 1 & 2.5051 & 1 & 3.1072 \\
8 & 0 & - & 0 & - \\
9 & 0 & - & 0 & - \\
10 & 0 & - & 0 & - \\
\hline ALL & 20 & $2.6105 \pm 0.3559$ & 19 & $2.5527 \pm 0.3790$ \\
HIGH & 9 & $2.8396 \pm 0.3821$ & 8 & $2.5804 \pm 0.3858$ \\
LOW & 5 & $2.3847 \pm 0.1649$ & 5 & $2.3847 \pm 0.5037$ \\
NO & 0 & - & & - \\
\hline
\end{tabular}

ALL = all animals considered together

HIGH $=$ herds where almost all sentinel calves became infected (nos. 1 and 2)

LOW = herds where few sentinel calves became infected (nos. 5, 6 and 7)

NO = herds where no sentinel calves became infected (nos. 8, 9 and 10)

II B1. Sentinel calves seronegative after grazing

Twenty-three seronegative sentinel calves became all seropositive 3 weeks after vaccination in 1981 (Table 4). The mean individual titre value was $1 / 640$ (range $1 / 80$ $1 / 10240$ ). There was no significant difference between the mean titre values of these on average 20.3-month-old animals and those of on average 9-month-old calves which were vaccinated in spring 1980.

\section{B2. Sentinel calves seropositive after gra-} zing

Nineteen sentinel calves, which were seropositive after their first season on grass, were still seropositive when vaccination was performed in spring 1981.
The mean individual titre value increased from $1 / 357$ (range $1 / 80-1 / 1280$ ) to $1 / 1028$ (range $1 / 320-1 / 5120$ ) in 3 weeks. There was no significant difference between the prevaccination and the post-vaccination mean titre values of primarily seropositive animals or the post-vaccination values of these 2 groups of animals.

No clinical babesiosis occurred in sentinel animals after vaccination.

\section{Discussion}

This study shows that the B.divergens vaccine manufactured by the National Veterinary Institute in Sweden is effective in producing specific IgG antibodies in calves and young cattle. The antibody titre reached was uninfluenced by the age of the animals, the age 
Table 4. Babesia divergens IgG antibody titres of previously unvaccinated sentinel calves at 3 weeks after vaccination. These animals were approximately 1 year older than those included in Table 2.

\begin{tabular}{lcccc}
\hline & & \multicolumn{2}{c}{${ }^{10}$ Log. reciprocal B.divergens antibody titres $\overline{\mathrm{x}} \pm$ S.D. } \\
\cline { 2 - 5 } Herd no. & $\mathrm{n}$ & $\begin{array}{c}\text { Animals seropositive } \\
\text { before vaccination }\end{array}$ & $\mathrm{n}$ & $\begin{array}{c}\text { Animals seronegative } \\
\text { before vaccination }\end{array}$ \\
\hline 1 & 5 & $3.0470 \pm 0.2518$ & 0 & - \\
2 & 3 & $3.1072 \pm 0.3010$ & 1 & 2.5051 \\
3 & 3 & $3.2070 \pm 0.3476$ & 2 & $3.1072 \pm 0.0000$ \\
4 & 3 & $3.1072 \pm 0.6021$ & 2 & $3.4082 \pm 0.0000$ \\
5 & 2 & $2.6557 \pm 0.2129$ & 3 & $2.4048 \pm 0.1738$ \\
6 & 2 & $2.6557 \pm 0.2129$ & 2 & $2.0536 \pm 0.2128$ \\
7 & 1 & 3.1072 & 4 & $2.8062 \pm 0.4257$ \\
9 & 0 & - & 5 & $3.2878 \pm 0.5868$ \\
10 & 0 & - & 4 & $2.5051 \pm 0.000$ \\
\hline ALL & 19 & $3.0121 \pm 0.3484$ & 23 & $2.8062 \pm 0.5293$ \\
HIGH & 8 & $3.0696 \pm 0.2512$ & 1 & 2.5051 \\
LOW & 5 & $2.7460 \pm 0.2519$ & 9 & $2.5051 \pm 0.4257$ \\
NO & 0 & - & 9 & $2.9399 \pm 0.5851$ \\
\hline
\end{tabular}

ALL = all animals considered together

HIGH $=$ herds where almost all sentinel calves became infected (nos. 1 and 2)

LOW = herds where few sentinel calves became infected (nos. 5, 6 and 7)

NO = herds where no sentinel calves became infected (nos. 8, 9 and 10)

difference of the 2 groups being approximately 12 months (Tables 2 and 4). Vaccine prepared from fresh blood and vaccine prepared from blood stored for a week were equally effective when distributed and handled as described by the manufacturer. Clinical babesiosis did not occur after vaccination of 329-month-old animals.

Animals 4-18 months old were vaccinated 1 to 2 months before they were let out on grass. They were all seropositive when first tested 3 weeks later. The individual mean titre values of vaccinated animals subsequently decreased significantly during the following 6 months, although the animals were on tick infested pastures. Therefore it may be suggested that the exposure of vaccinated animals to a natural challenge do not necessarily enhance the antibody response. Sup- port for this suggestion comes from the observations that a) vaccination of naturally infected seropositive calves gave no significant rise of the individual mean antibody titre (Tables 3 and 4), b) the antibody titre value of calves in high infection risk herds did not differ from that in no risk herds after vaccination $c$ ) the individual mean antibody titres were equal for vaccinated and naturally infected seropositive calves after the grazing period (Tables 2 and 3). Furthermore, the herd mean antibody titres were relatively consistent up to 1 year after vaccination (Table 2).

The antibody titres were actually increased in some animals after housing although no exposure to natural infection could be expected. This increase of at least 2 doubling dilution steps or more, was regarded as signifi- 
cant for the IF-test (Chisholm et al. 1978, Christensson 1987). Ross \& Löhr (1968) reported a similar result for B.bigemina. The explanation may be the antigenic variation occurring in Babesia infections (Curnow 1973), and both natural infection and vaccination usually cause a chronic infection in the animals (Mahoney 1969, Johnston \& Tammemagi 1969, Mahoney et al. 1973).

Two out of 19 naturally infected sentinel calves on different farms had clinical babesiosis when on grass whereas all 49 vaccinated calves still included in the study in 1980 were healthy throughout the grazing season ( $p$ $<0.1$ ). This tendency is in agreement with previous reports on vaccination for B.bovis on beef cattle in Australia. Emmerson et al. (1976) and Callow et al. (1976) showed that $17.9 \%$ of unvaccinated and $1.2 \%$ of vaccinated animals got clinical babesiosis. The infection rate in their 4-year study was $49-69 \%$ in the 6-18-month-old animals. The infection rate in sentinel animals in the present study was $41.7 \%$. The 2 calves with clinical babesiosis were seronegative when symptoms were first observed. This observation, previously noted by Ross \& Löhr (1968) and Todorovic \& Carson (1981), shows that the disease was caused by a primarily tick-inoculation of B.divergens organisms. The number of seropositive sentinel animals in the individual herds varied after the first grazing season. In herds nos. 8-10 no sentinel calf was seropositive for B.divergens (Table 1). This is remarkable because the other animals on these farms had been vaccinated with a live B.divergens vaccine and consequently they were chronic carriers as described for B.bovis and B.bigemina by Mahoney (1969), Johnston \& Tammemagi (1969) and Mahoney et al. (1973). Therefore it is postulated that the sentinel animals were kept in an Ixodes ricinus-free environment during the actual grazing period.
On some farms (nos. 1-2) the infection pressure, as judged from the number of infected sentinel animals, was high enough to ensure an annual booster-infection and thereby a persistent protection of older animals during the following grazing seasons. On other farms, having a lower infection pressure (nos. 5-7), grown up animals will probably be at risk of contracting clinical babesiosis in subsequent summers. In forming this judgement, information about the epidemiology and vaccination of B.bovis, published by Mahoney (1976), has been taken in consideration.

In contrast to Weisman et al. (1974), working with B.bovis and B.bigemina, maternal IgG antibodies were not detected in sera from 14 calves aged 3-5 months, although their dams most probably were infected. This indicates that maternal antibodies against B.divergens will not be that obstacle for serological surveys with the IF-technique as discussed by Aragon (1976). Consequently the applied method is relevant under Swedish conditions, because B.divergens is the only species so far being demonstrated in cattle in this country.

In conclusion, the B.divergens vaccine used in Sweden produces antibodies after s.c. inoculation, and it is safe for calves and young animals. Natural infection of vaccinated animals seems not to cause a booster effect on the IgG response. It is obvious that vaccination of calves even within a tick area is not necessarily beneficial from a clinical and economical point of view, especially in herds with a high infection risk and subsequent contacts between the hosts and the parasite. However, the decision to vaccinate or not requires a close knowledge of tick ecology and animal management on each individual farm, and preferably an investigation encompassing more than one grazing season. 


\section{References}

Aragon $R$ S: Bovine babesiosis: A review. Vet. Bull. 1976, 46, 903-917.

Bodin S, Hlidar G: Skyddsympningar i Sverige mot piroplasmos (Vaccination against piroplasmosis (babesiosis) in Sweden). Proc. 9th Nordic Vet. Cong. Copenhagen 1963, p. 328-333.

Callow L L: Vaccination against bovine babesiosis. In: Immunity to Blood Parasites of Animals and Man. (ed. Miller, L. H., J. Pino \& Jr. J. McKelvey) 1977 , p. 121-150.

Callow L L, Emmerson F R, Parker $R$ J, Knott $S G$ : Infection rates and outbreaks of disease due to Babesia argentina in unvaccinated cattle on 5 beef properties in south-eastern Queensland. Aust. vet. J. 1976, 52, 446-450.

Chisholm E S, Ruebush II T K, Sulzer A J, Healy G $R$ : Babesia microti infection in man: Evaluation of an indirect immunofluorescent antibody test. Am. J. trop. Med. Hyg. 1978, 27, 14-19.

Christensson D: A modified IF-test to demonstrate IgM antibodies to Babesia divergens of cattle. Acta. vet. scand. 1987, 28, 361-371.

Curnow $J A$ : Studies on antigenic changes and strain difference in Babesia argentina infections. Aust. vet. J. 1973, 49, 279-283.

Emmerson F R, Knott S G, Callow L L: Vaccination with Babesia argentina in 5 beef herds in southeast Queensland. Aust. vet. J. 1976, 52, 451454.

Goldman M: Fluorescent Antibody Methods. Academic Press, N.Y. 1968.

Goldman M, Pipano E: Serological response in field cattle immunized against Babesia berbera. Trop. Anim. Hlth. Prod. 1974, 6, 123-127.

Heijbel $H$ : Piroplasmosen, behandling och skyddsympning (Piroplasmosis, treatment and vaccination). 3 Nordiske Vet. möte, Oslo, 9-11 juli 1928, p. 166-178.

Johnston L A Y, Tammemagi L: Bovine babesiosis: Duration of latent infection and immunity to Babesia argentina. Aust. vet. J. 1969, 45, 445-449.

Joyner L P, Davies SFM: Acquired resistance to Babesia divergens in experimental calves. J. Protozool. 1967, 14, 260-262.

Mahoney $D F$ : Bovine babesiosis: a study of factors concerned in transmission. Ann. trop. Med. Parasit. $1969,63,1-14$.
Mahoney D F: Babesia of domestic animals. In Parasitic Protozoa, IV, ed. Kreier, J. P. Academic Press, London 1976, p. 1-52.

Mahoney D F, Wright I G, Mirre G B: Bovine babesiosis: The persistence of immunity to Babesia argentina and B. bigemina in calves (Bos taurus) after naturally acquired infection. Ann. trop. Med. Par. 1973, 67, 197-203.

Olson $\mathrm{H}$ : Studien über das Auftreten und die Verbreitung der Rinderleukose in Schweden (Studies on the occurrence and distribution of bovine (enzootic) leucosis in Sweden). Acta vet. scand. 1961, 2, suppl. 2, 13-46.

Purnell $R$ E, Lewis D, Brabazon A, Francis L $M A$, Young $E R$, Grist $C$ : Field use of an irradiated blood vaccine to protect cattle against redwater (Babesia divergens infection) on a farm in Dorset. Vet. Rec. 1981, 108, 28-31.

Ross J P J, Löhr K F: Serological diagnosis of Babesia bigemina infection in cattle by the indirect fluorescent antibody test. Res. Vet. Sci. 1968, 9, 557-562.

Taylor S M, Kenny J, Purnell R E, Lewis D: Exposure of cattle immunized against redwater to tick challenge in the field: Challenge by a homologous strain of B. divergens. Vet. Rec. 1980, 23, 167-170.

Todorovic R A, Lopez L A, Lopez A G, Gonzalez E $F$ : Bovine babesiosis and anaplasmosis: Control by premunition and chemoprophylaxis. Expl. Parasit. 1975, 37, 92-104.

Todorovic $R A$, Carson $C A$ : Methods for measuring the immunological response to Babesia. In Babesiosis, ed. M. Ristic \& J. P. Kreier, 1981, p. 381410.

Trees $A \mathrm{~J}$ : The application of acridin orange staining to quantitative low levels of Babesia divergens parasitaemia. Trans. R. Soc. trop. Med. Hyg. 1974, 68, 277.

Wahlgren $M$, Christensson $D$, Bergquist R, Björkman A, Pehrsson P O, Rombo L: Babesios, en risksjukdom för immunodefekta i Sverige (Babesiosis, a disease at risk for people with immunodeficiency disease in Sweden). Opusc. med. 1984, 29, 26-28.

Weisman J, Goldman M, Mayer E, Pipano E: Passive transfer to newborn calves of maternal antibodies against Babesia bigemina and Babesia berbera. Refuah vet. $1974,31,108-113$. 


\section{Sammanfattning}

Antikroppssvar (IgG) efter vaccination eller efter naturlig infektion med Babesia divergens hos nötkreatur.

Antikroppssvaret hos kalvar efter vaccination mot babesios undersöktes med en indirekt immunofluorescensteknik. I försöket ingick 10 besättningar vilka vaccinerat regelbundet $i$ minst 5 år. Blodprov togs från 5 kalvar före vaccination, 3 veckor efter, efter installning samt ca 1 månad före nästa betessläppning. I samma besättningar lämnades 5 kalvar ovaccinerade. Prov togs även från dessa vid samma tillfällen som från de vaccinerade. Före följande års betessläppning vaccinerades de tidigare ovaccinerade kalvarna och prov togs från dessa 3 veckor efter vaccination.

Tre veckor efter vaccination var alla kalvar seropositiva, såväl de som vaccinerades före första betessläppningen som de som vaccinerades följande vår. Någon skillnad $i$ antikroppstiter sågs ej trots att åldersskillnaden mellan grupperna var 12 månader. Inte heller sågs några kliniska reaktioner efter vaccination i någon av dessa grupper. Ovaccinerade kalvar seronegativa före betessläppning.

Efter betessäsongen var $\mathbf{4 2}$ av dessa kalvar seropositiva, 2 hade behandlats för akut babesios under juliseptember.

Trots att alla gårdar vaccinerade årligen varierade antalet naturligt infekterade kalvar kraftigt från gård till gård. På 2 gårdar blev 4 resp. 5 av de 5 ovaccinerade kalvarna seropositiva under det att på 3 gårdar blev ingen ovaccinerad kalv seropositiv. Detta är troligen en följd av stora variationer i förekomst av fästingar på de olika betena.

Alla kalvar som var seropositiva vid installningen var det även före nästa års betessläppning. Antikroppstitrarna hade oftast sänkts något. Medelvärdet skiljde sig ej signifikant från titermedelvärdet av seropositiva djur vid installning.

\section{(Received May 27, 1987).}

Reprints may be requested from: Dan Christensson, National Veterinary Institute, Dept. of Parasitology, P. O. Box 7073, S-750 07 Uppsala, Sweden. 